\title{
The Shadow of Death: An Empirical Analysis of the Pre-Exit Performance of Young German Firms ${ }^{\dagger}$
}

by

\author{
Matthias Almus \\ Centre for European Economic Research (ZEW), Mannheim
}

\begin{abstract}
This paper makes an empirical contribution to confirm the stylized fact that the performance of firms deteoriates in the years before exit. For this reason we evaluate whether market exits differ significantly in their employment development in the years before market drop-out compared to surviving firms that have been selected using a non-parametric matching approach. The matching approach allows to find a surviving firm for every market exit that does not differ in important characteristics measured at start-up. The comparison of the employment growth rates among the thus formed groups reveals that the matched surviving firms experience higher growth rates compared to their exiting counterparts up to three years before market exit. Moreover, we find support for the phenomenon called "shadow of death" sneaking around the corner. A considerable number of firms exiting from 1995 until 1998 has experienced continuing employment losses or at least an employment stagnation over several years before market exit.
\end{abstract}

Keywords: New Firms, Employment Growth, Evaluation, Non-Parametric Matching.

JEL Classification: L21, C14.

address: ZEW, Centre for European Economic Research,

Department of Industrial Economics and International Management

P.O.Box 1034 43, D-68034 Mannheim

phone: $\quad+49 / 621-1235-185$

fax: $\quad+49 / 621-1235-170$

E-mail: almus@zew.de

\footnotetext{
${ }^{\dagger}$ Financial support from the Deutsche Forschungsgemeinschaft (DFG) within the main focus "Interdisciplinary Research on Firm Foundation" is gratefully acknowledged. Thanks to Georg Licht and Joachim Wagner for helpful comments, Heide Crawford for proof-reading and Sven Klosse for formatting the paper. All errors that remain are, of course, the responsibility of the author alone.
} 


\section{Non-technical summary:}

The point of departure for this study is the fact that many start-ups do not survive the first years of existence. Although many studies have examined factors that influence the survival of firms, up to now economists have neglected to examine the development on the way to market drop-out. Research questions of particular interest are as follows: Do peculiarities exist in the employment development prior to market drop-out? Is there a point in time during which firms recognise that they cannot survive? And is there an observable point in time during which firms start to adjust employment downward to prepare for the market drop-out? The data source used comes from a survey of 12,000 Eastern and Western German firms founded at the beginning of the 1990s. The survey, for which information regarding the post-entry performance was gathered, resulted in about 3,700 interviews. This paper will make an empirical contribution to confirm the stylised fact that market exits achieve a worse performance in the years before they exit. For this reason the paper will evaluate whether market exits differ significantly in their employment development in the years before market drop-out compared to surviving firms that have been selected using a non-parametric matching approach that has often been applied in labour economics up to now. The comparison of the employment growth rates among the thus formed groups reveals that in most cases the matched surviving firms experience higher growth rates compared to their exiting counterparts in the years before market exit. Pooling of the data leads to significant differences in the growth paths in favour of the matched surviving firms up to 3 years before the market drop-out of the exiting firms. Moreover, the data used indicate that there exists a "shadow of death" sneaking around the corner. A considerable number of firms that exited from 1995 until 1998 has experienced continuing employment losses or at least an employment stagnation over several years before market exit. 


\section{Introduction}

Numerous studies in Industrial Economics deal with survival (Brüderl et al. 1992, Harhoff et al. 1998, Prantl 2000) and the growth of new and established firms (Evans 1987, Harhoff et al. 1998). Moreover, various papers evaluate the employment-creating potential of new and of established firms (Rajan and Zingales 1998). The results found hold for different countries, time periods and industries and lead to a number of stylized facts. First, there is a strong correlation between market entry and exit rates for various industries (Geroski 1995, Caves 1998). Second, the distribution of firm size is highly skewed to the right and approximately follows a log-normal distribution (Schmalensee 1989). Moreover, initial firm size has a negative influence on growth in subsequent periods, indicating a deviation from Gibrat's Law at least for small firms (Sutton 1997). Last but not least, numerous empirical studies found that firm size and age influence the growth of young firms negatively, but the survival positively (Evans 1987, Audretsch 1995).

All these facts concern the post-entry performance of firms. Point of departure for this study is the fact that many start-ups do not survive the first years (Storey 1994). Although many studies have examined factors that influence the survival of firms, economists have neglected to examine the development of the way to market drop-out hitherto. Research questions of special interest are: Do peculiarities exist in the employment development prior to market drop-out? Is there a point in time in which firms recognize that they cannot survive? And is there an observable point in time in which firms start to adjust employment downward to prepare for the market drop-out?

Only a few studies exist that deal with this so called pre-exit performance of firms. Wagner (1999) examines the life history of three cohorts of exiting manufacturing firms in the German federal state Lower Saxony. The main result is that there is no "shadow of death" sneaking around the corner, i.e. firms that exit the market do not experience a gradual employment decline 
over several years before market exit. Olley and Pakes (1996) use data from the telecommunication equipment industry to estimate a production function. They find empirical support that the firm's productivity is a major determinant of whether or not a firm exits.

This paper makes an empirical contribution to confirm the stylized fact that market exits achieve a worse performance in the years before exit. For this reason we evaluate whether market exits differ significantly in their employment development in the years before market drop-out compared to surviving firms that have been selected using a non-parametric matching approach. The matching approach permits to find a surviving firm for every market exit that does not differ in important characteristics measured at start-up. Since the firms do not differ in observable characteristics at start-up, either unobservable factors lead to the worse performance or conditions that presuppose the market drop-out develop over time.

The comparison of the employment growth rates among the thus formed groups reveals that in most cases the matched surviving firms experience higher growth rates compared to their exiting counterparts in the years before market exit. Pooling of the data leads to significant differences in the growth paths in favor of the matched surviving firms up to three years before market dropout of the exiting firms. Moreover, the data used indicate that there exists a "shadow of death" sneaking around the corner. A considerable number of firms exiting from 1995 until 1998 has suffered from continuing employment losses or has exhibited at least an employment stagnation over several years before market exit.

This paper is organized as follows. The next section briefly presents the data and section 3 contains some descriptives. Section 4 presents the matching procedure and the success analyses, i.e. the results from the subsequent comparison of employment growth rates between both groups. The last section summarizes the findings. 


\section{Data}

The data set contains 12,000 observations that have been included in a telephone questioning in 1999 (Almus 2000). ${ }^{1}$ About 135,000 observations from the ZEW Foundation Panel West, as well as more than 112,000 firm units from the ZEW Foundation Panel East form the parent population (Almus et al. 2000). All firms considered for the drawing of the sample have an earliest foundation date that was between 1990 and 1993 reported by CREDITREFORM ${ }^{2}$, and operate in the manufacturing, building, trade or selected branches of the service sector and do not have the legal forms of freelance, registered society or registered cooperative. First of all, there is a stratification with respect to Eastern and Western German firms. 6,000 firms each build the sample. Second, the other main stratification criterion is an indicator ${ }^{3}$ that gives information as to whether the respective firm has possibly exited the market or is still active. We oversample firms with these indicators when drawing the sample to get a satisfactory number of interviews with exiting firms for the empirical analyses since these firm groups show a worse response behavior compared to market active firms (Almus 2000).

The survey aims to obtain firm information relating to

- a possible market exit (date, reasons, financial losses to several parties),

- the market entry (foundation type, date, legal form etc.),

- organizational changes (legal form, merger, acquisition etc.)

- the firm owners (firms and/or persons separated in the categories Eastern and Western Germany and foreign countries)

- the annual development of the number of employees and

- the receipt of public support.

\footnotetext{
${ }^{1}$ The questioning is part of a project co-financed by the Deutsche Forschungsgemeinschaft (DFG) and entitled "Survival, growth and fast growth of start-ups in Eastern and Western Germany".

${ }^{2}$ CREDITREFORM is the largest German credit rating agency.

3 This indicator based on information of CREDITREFORM and points to problems in handling the data set or to different stages of bankruptcy proceedings.
} 
We used a CATI system ${ }^{4}$ to carry out the survey that was divided into 3 stages. In the first stage, a firm representative was expected to answer the survey. Afterwards, a firm owner was chosen for all firms that did not answer the survey completely in the first stage. If no contact could be established with the selected owner person or the person refused to answer the survey questions, a second owner person was chosen.

With 3,702 completed interviews ${ }^{5}$ out of 12,000 sample observations, the response rate was about 31 per cent, which is relatively high compared to other German studies conducted by telephone. ${ }^{6}$ Further restrictions with respect to the date of start-up, employment figures and the type of foundation are necessary to obtain the data set for the empirical analyses. Observations for the present study have a foundation date between 1990 and 1993 and complete annual employment histories to track the observations over time. Moreover, firms must be true start-ups, i.e. this study excludes partial and complete take-overs from the following analyses. This yields a data set containing 1,795 observations, 507 of which are market exits.

Apart from the information conducted in the interviews, other details from the ZEW Foundation Panels East and West (e.g. human capital of the firm participants) and from external data sources (e.g. classification of regional origin (BFLR 1995)) are available.

\section{$3 \quad$ Descriptives}

Table 1 contains descriptive statistics of the main variables used for the empirical analyses. The average number of employees at start-up is about 7 , whereas the median, a measure that is less suspectible to outliers, is 3 . The median confirms the findings of other studies that new firms start very small

\footnotetext{
${ }^{4}$ CATI stands for computer assisted telephone interviewing.

5 The term "complete interviews" refers to a final status of the CATI system. Nevertheless the individual observation differ in their information content.

${ }^{6}$ For analyses dealing with the survival of firms a statement regarding the survival status is possible for additional 2,234 firms.
} 
and create in most cases only a workplace for the founder(s). Additionally, we analyzed the employment development by means of kernel density estimates (Yatchew 1998). For the years 1990-1999 the distribution of the firm size is skewed to the right and approximately follows a log-normal distribution (Schmalensee 1989, Sutton 1997). ${ }^{7}$ The average number of employees and the median increase over time. The mean (median) increased from about 8 resp 3 employees in 1990 to 11 resp 5 employees in 1999.

$$
>\text { insert Table } 1 \text { about here }<<
$$

The annual employment growth rates are positive (except for the period from 1998 to 1999) but decrease over time. The decrease in the annual employment rates is due to an increase of the number of firms (new start-up cohorts) over time used to calculate the growth rates. The older the firms the weaker is the age influence on the growth rate (Evans 1987), thus indicating a decrease of the annual employment growth. Moreover, most firms in the data set neither grow nor shrink at all. The median growth rate in all years equals 0 . And only a small number of firms realize above average growth rates and belong to the so-called group of "gazelles" or "fast growing firms" (Storey 1994, Brüderl and Preisendörfer 2000).

In addition to this, Table 1 presents dummy variables that contain information on the year of foundation, the industry classification and the legal form, i.e. whether they had been founded under one of the following liability limiting legal forms: GmbH or GmbH\&Co.KG (limited liability company) or AG (joint stock company). The remaining dummy variables indicate the number of owner persons involved in the foundation process, the human capital endowment of the founder(s) as well as two dummy variables that state whether the firm was founded in Eastern or Western Germany and if other firms were involved

\footnotetext{
7 Figure 1 in the appendix contains the results of the kernel density estimates. The analysis includes all firms with valid employment numbers in the respective year.
} 
in the foundation. Additionally, three dummy variables indicate the regional density of the counties where the firms come from. The three groups (high density, medium density and low density) were derived from a classification of German counties from the BFLR (1995)

\section{Empirical analyses}

\subsection{Method}

Up to now the data set contains observations of market exits $\left(N_{\text {exit }}=507\right)$ and surviving firms $\left(N_{\text {survive }}=1,288\right)$ that differ significantly in important characteristics measured at start-up. A computation of the growth rates for the market exits in the years before exit is quite easy. But, we are not able to measure the respective employment effects for the surviving firms before market drop-out since these are still alive. A comparison of the average growth rates of both groups at this time would lead to biased results because of these differences. In the statistical analysis we want to evaluate the performance of the market exits in the years prior to death and compare this with the performance of firms that survive but do not differ from the exiting firms in basic firm characteristics measured at start-up. These characterictics include

- initial firm size,

- year of foundation,

- industry classification,

- regional origin,

- human capital of the founder,

- legal form and

- existence of participants (owner persons as well as firms).

The best and easiest way to find a partner for every exiting firm is to select the surviving one with exactly the same values in the selected matching variables. But the relative high number of these variables and the availability of only 
about 1,300 matching partners impede this approach.

To circumvent these difficulties non-parametric matching methods which became popular recently in labor-market evaluation studies represent a powerful alternative (Lechner et al. 2000). Rosenbaum and Rubin (1983) point out that matching "[...] is a method for selecting units from a large reservoir of potential comparisons to produce a comparison group of modest size in which the distribution of covariates is similar to the distribution in the treated group.". For this reason non-parametric matching represents a good method to evaluate the pre-exit performance of the market exits.

The matching algorithm used corresponds closely to the one applied by Hujer et al. (1997). To reduce the multidimensional problem arising from the relatively high number of covariates to a one-dimensional problem, we estimate a probit model initially (Maddala 1983). ${ }^{8}$ The decision $\left(y_{i}\right)$ whether the firm has exited the market $\left(y_{i}=1\right)$ or not $\left(y_{i}=0\right)$ serves as the endogenous variable. The probit model estimates if firm $i$ has left the market

$$
E\left[y_{i} \mid x_{i}\right]=\operatorname{Pr}\left(y_{i}=1 \mid x_{i}\right)=\Phi\left(x_{i}^{\prime} \beta\right) \quad \forall i=1 \ldots N
$$

given a vector $x_{i}$ containing the set of matching characteristics. $\Phi(\bullet)$ is the cdf of the standard normal and $\beta$ is the parameter vector to be estimated. After estimating the probit model the unbounded score $x_{i}^{\prime} \hat{\beta}$ is calculated for every observation. We prefer the unbounded rather than the bounded propensity score $\Phi\left(x_{i}^{\prime} \hat{\beta}\right)$ because it has preferable distribution properties (Hujer et al. 1997 $)^{9}$. The upper half of Figure 2 shows histograms for the unbounded propensity score $\left(x^{\prime} \hat{\beta}\right)$ before the matching process started. They fulfil an important assumption for the matching process since both graphs overlap to a great extent and hence indicating similar distributions of the two groups (Lechner et al. 2000).

$>$ insert Figure 2 about here $<<$

\footnotetext{
8 The results of the probit model are not reported but available upon request.
}

${ }^{9}$ See also the literature cited in this paper. 
The matching process proceeds then as follows:

1. Divide the firm observations with respect to their survival status.

2. Randomly select a market exit $i$.

3. Take the unbounded propensity score $x^{\prime} \hat{\beta}$ and the vector $\alpha$ (where $\alpha$ is a subset of $x$ ) that contains important matching variables significant at the 5 per cent level in the probit estimate (initial firm size, start-up year as well as a dummy variable indicating if the firm comes from Eastern or Western Germany ${ }^{10}$ ) to calculate the distance

$$
d_{i j}=\left(x_{i}^{\prime} \hat{\beta}, \alpha_{i}\right)^{\prime}-\left(x_{j}^{\prime} \hat{\beta}, \alpha_{j}\right)^{\prime} \forall j=1 \ldots N_{\text {survive }}
$$

for every combination of the market exit $i$ and every surviving firm $j$. Then calculate the Mahalanobis distance

$$
M D_{i j}=d_{i j}{ }^{\prime} \operatorname{Cov}^{-1} d_{i j} \quad \forall j=1 \ldots N_{\text {survive }}
$$

to find the nearest neighbor. Cov represents the covariance matrix based on the surviving firms.

4. The surviving firm $j$ with the smallest Mahalanobis distance serves as a control observation in the following success analysis. If more than one firm has the same Mahalanobis distance the comparison observation is drawn randomly.

5. Remove the $i$-th firm from the pool of market exits but return the selected control observation in the pool of surviving firms. This is done because of the relatively small number of surviving (control) firms.

6. Repeat steps 2. to 5 . to find the matched pairs for all market exits.

\footnotetext{
${ }^{10}$ This dummy variable was overweighted tenfold to ensure that the counterpart of every Western (Eastern) German exiting firm is a Western (Eastern) German surviving firm.
} 


\subsection{Results}

Table 2 measures the statistical "similarity" of the observations that remain after the matching procedure. Colums 2 and 3 contain the means of the variables of the exiting and the matched surviving firms. Matching is regarded as successful if the means of the relevant variables in both groups do not differ significantly. For this reason the fourth row of Table 2 contains the values of mutual t-tests that the differences of the means in both groups equal zero. For most variables the differences are small and not statistically significant. Only the shares of firms operating in wholesale and building (basic construction) differ significantly between both groups at the 5 resp. 10 per cent level of significance in the mutual t-test (see Table 2). Moreover, the unbounded propensity score $\left(x^{\prime} \hat{\beta}\right)$, as a summary measure of various variables, does not differ significantly between both groups, indicating a good fit of the matching algorithm applied. The lower half of Figure 2 shows kernel density estimates of the unbounded propensity scores for both groups. The overlap is nearly perfect $^{11}$ and underlines the quality of the matching procedure.

$$
>\text { insert Table } 2 \text { about here }<<
$$

In the empirical analyses the year-to-year continuous growth rate

$$
\text { growth }_{t, t-1}=\ln \left(\text { employment }_{t}\right)-\ln \left(\text { employment }_{t-1}\right)
$$

serves as a success indicator. ${ }^{12}$ Table 3 contains the average growth rates for the firms that belong to the exit cohorts 1995 until 1998 as well as the mean growth rates of the matched control groups, i.e. surviving firms. We compare the growth rates of both groups up to four years prior to the exit year of the

\footnotetext{
11 Here, kernel density estimates instead of histograms serve as tool to show the similarity in the relative frequencies (probability density) since both groups contain the same number of observations after the matching process.

12 The results only change marginally when the discrete growth rate growt $_{t, t-1}=\left(\right.$ employment $_{t}-$ employment $\left._{t-1}\right) /$ employment $_{t-1}$ is used. In addition, the specification used is only valid for small growth rates. The small mean growth rates, however, support the approach used.
} 
respective cohorts. Not surprisingly, all exit cohorts realize significant lower growth rates than their matched partners in the year of market exit. More interesting is the evaluation in the years before to obtain more information of whether and when firms that will leave the market start to reduce their employment. In the year before market exit all cohorts perform worse on average, though it should be noted that the difference is not significant for the 1996 exit cohort. Two years prior to exit the mean growth rates of the comparison observations are still higher but statistically significant only for the 1996 exit cohort. Three years before market exit significantly higher growth rates of the surviving firms appear again for the 1996 cohort. For the 1995 cohort the exiting firms perform better but the values rarely differ. In the last time period observed significant differences only appear for the 1995 exit cohort. For the 1998 and 1996 cohorts the exiting firms have slightly higher growth rates. In the remaining two cohorts the survivors perform better. All these things together, the results indicate that the exiting firms show a worse performance compared to the matched surviving firms in the years before exit. ${ }^{13}$

$>$ insert Table 3 about here $<<$

To control this finding a pooling of the observations from all exiting cohorts takes place. A comparison of the average growth rates leads to significantly higher values in the group of the matched surviving firms in all periods up to three years before market drop-out (see last column in Table 4). ${ }^{14}$ This finding supports the result obtained that market exits perform worse in the last three years of existence compared to firms that survive. Since the firms do not differ in observable characteristics at start-up we compare two groups with equal initial conditions. Unobservable characteristics at start-up or conditions

\footnotetext{
${ }^{13}$ Due to the relatively small number of observations, significant differences do not appear in all observed cases.

14 The increased number of observations in the t-tests is one reason for these significant differences.
} 
that presuppose the market drop-out over time influence the probability of a market exit and seperate the firms later on. At some point in time the firms recognize that their productivity level is not viable. This is in accordance with Ericson and Pakes (1995). Firms owners can pursue two possible strategies at this point. First, they have a strong connection with the firm and want to stay in the market as long as possible (passive strategy). These owners will reduce employment gradually until the day of market exit. Second, the owners recognise that firm productivity to low to survive. Hence, they dismiss employees to raise the productivity to a viable level (active strategy). But in many cases these firms will nevertheless leave the market in the end. The empirical analyses show that a period of time exist between recognizing a not viable productivity level and exiting the market in case of both strategies. One thing the firms do is to reduce employment. The results of the analyses show that the employment adjusting process starts approximately 3 years prior to market exit.

$$
>\text { insert Table } 4 \text { about here }<<
$$

An interesting picture emerges when we run separate pooled analyses for Western and Eastern Germany. Since the matching process yielded nearly the same number of observations from Western and Eastern Germany in the groups of exiting and surviving firms, this separation can be carried out (see mean comparison in Table 2). ${ }^{15}$ The familiar pattern ermerges for Western German firms. The matched comparison observations show higher growth rates up to three years before market exit. Significant differences, however, appear in the group of Eastern German firms only in the year of market exit and in the year before. This might be an indicator that the time period between anticipating and realizing the market exit is shorter for Eastern German firms. Better fi-

\footnotetext{
15 Only in two cases the partner for an exiting firm from Western Germany was an Eastern German surviving firm.
} 
nancial resources of Western German firms which can postpone the impending market exit longer may be one reason for this observation. Moreover, uncertain economic conditions in Eastern Germany and firm founders with only few entrepreneurial experiences led to market exits immediately after recognizing that the firm is not viable.

Additionally, it was tested how many of the exiting firms of every cohort experienced gradual employment losses or did not change their number of employees in the years prior to market exit. Table 5 summarises the results that differ somewhat from those in Wagner (1999). ${ }^{16}$ Between 23 and 71 percent of the exiting firms decrease their employment or at least stagnate over a time period of 5 years before market exit. These shares increase steadily when moving to the point of market exit (see Table 5). The higher share of firms that reduce employment or stagnate over a 5-year-interval for later exit cohorts is partly due to business cycle effects. The reunification boom implies a smaller probability of shrinking employment over a certain time period in the early 1990s in comparison to the end of the decade. And firms that left the market in 1995 and had been observed for a 5 year period had gained to a greater extent from this boom phase than firms that left the market in subsequent years. Therefore, during an economic recession a downward adjustment in the number of employees is more likely for a firm that leaves the market at the end of the 90s.

$$
>>\text { insert Table } 5 \text { about here }<<
$$

To check these results we use the surviving comparison firms as a benchmark (see lower part in Table 5). Not surprisingly, the survivors do not exhibit decreasing or stagnating employment patterns as often as the exiting firms.

\footnotetext{
${ }^{16}$ Four points must be mentioned here to understand the different results. Wagner (1999) uses businesses instead of firms and he does not restrict the analyses to new firms. Moreover, he concentrates on the manufacturing sector in the federal state of Lower Saxony.
} 
But the shares increase if the evaluation period becomes shorter, i.e. the "hypothetical" point of market exit comes closer. The differences between both groups (i.e. exits and survivors) range from about 6 to 34 per cent. Similar to the exiting firms we observe a business cycle effect for the matched survivors, too. This confirms the findings for the market exits. Surviving firms assigned to exits in 1998 reveal higher shares of firms with decreasing or stagnating employment patterns than firms assigned to exits in 1995. While the period under evaluation falls mainly in a economic recession for the 1998 cohort, the 1995 cohort gained from the reunification boom.

$>$ insert Table 6 about here $<<$

The German economy experienced after the reunification considerable economic growth in the beginning of the 90s (boom period) followed by shrinking growth (recession) since 1995 (see Table 6). Firms founded at the beginning of the boom phase (1990 or 1991) had a higher probability to break even faster than firms founded in 1992 or 1993. After break even the firms could build up ressources enabling them to resist bad economic conditions for a longer time. Hence, the earlier the firms have been founded the longer they could build up ressources before the recession started. Firms that exited the market in 1995 or 1996 have foundation dates in 1990 and 1991 and the matched surviving firms, too, since the year of start-up was a major matching criterion. ${ }^{17}$ Market exits in 1997 or 1998, however, have foundation dates between 1990 and 1993. These firms faced worse economic conditions in the years prior to market exit compared to the exit cohorts of 1995 and 1996. And this partly explains the higher shares of firms with continuing employment reductions or stagnation in the years before market exit.

\footnotetext{
175 observations in the group of surviving firms have an other year of foundation than their counterparts from the group of exiting firms.
} 


\subsection{Sensitivity of the results}

One point must be mentioned in connection with these results. Due to the fact that some surviving firms have the exact same values in the matching characteristics, the results in the success analysis may change slightly when matching takes place several times. This is so because every time the matching procedure is carried out, the observations are sorted randomly and surviving firms with the same set of characteristics exhibit the same Mahalanobis distance with respect to a given exiting firm. In case these distances are the smallest ones for the selected exiting firm, the selection of the comparison observation occurs randomly and may change from time to time. However, this does not change the main results of the analysis. The matched surviving firms experience higher growth rates in the years before exit for all exit cohorts. The significance of these differences, however, changes in some cases.

Moreover, to test the sensitivity of the obtained results the data sample at hand was extended in several ways:

- include observations with the foundation dates 1989 and 1994,

- include observations that have up to two missing employment figures that are not in the beginning or end of the employment history and interpolate them,

- include observations that are partial or complete take-overs but have a foundation date from 1990 until 1993

The inclusion of these observations does not change the main results. ${ }^{18}$ The matched surviving firms show higher growth rates in the years before market exit, but the number of significant differences changes. The results, however, remain stable for the pooled groups. The growth differences are significant up to three years before exit for all specifications in the groups of all and Western German firms and up to one year before market exit for the Eastern German firms.

\footnotetext{
18 The results are not reported, but are available on request.
} 


\section{Summary}

Using a rich data set of firms founded at the beginning of the 1990s we examine the performance of market exits in the years before market drop-out. In the analyses the growth patterns of firms that survive but do not differ in important characteristics measured at start-up serve as a benchmark. A non-parametric matching procedure was applied to generate this group of potential comparison observations. In this way the paper contributes empirically to confirm the stylized fact that market exits start to deteriorate in their performance a few years before the drop-out when they have realized that their strategy is not viable.

The results can be summarized as follows. First, firms belonging to different exit cohorts achieve on average smaller growth rates compared to the surviving firms selected. The differences remain up to three years before market drop out of the respective cohort and are significant in a number of cases. Pooling the observations of the individual exit cohort leads to a significantly better performance of the selected surviving firms up to three years before market drop-out. This indicates that the point in time in which firms start to prepare their future market drop-out is about three years before it actually happens. The results indicate that performance differences between both firm groups are not at all random, i.e. business cycle, demand fluctuations, rationalization processes etc. Firms that exit the market rather anticipate this fact and react with gradual downward employment adjustments in the years before market exit. Separate analyses for Eastern and Western Germany reveal that the time period between anticipating and realizing the market exit is shorter in Eastern Germany than in Western Germany.

Second, the phenomenon called "shadow of death" sneaking around the corner exists using the data set. There is a considerable number of exiting firms that experience continuing employment losses or an employment stagnation over a certain time period before market exit. 
Third, a business cycle effect becomes obvious. Firms that exit in 1995 as well as their surviving counterparts perform better in the years before exit than firms belonging to the remaining cohorts. 


\section{References}

Almus, M., D. Engel and S. Prantl (2000), The "Mannheim Foundation Panels" of the Centre for European Economic Research (ZEW), Documentation 00-02, Centre for European Economic Research (ZEW), Mannheim.

Almus, M. (2000), Befragung zur Post-Entry-Performance von Unternehmensgründungen in Ost und Westdeutschland, mimeo, Centre for European Economic Research (ZEW), Mannheim.

Audretsch, D.B. (1995), Innovation and Industry Evolution, MIT Press, Cambridge (Mass.).

Brüderl, J. and P. Preisendörfer (2000), Fast growing businesses. Empirical evidence from a German study, forthcoming in: International Journal of Sociology.

BFLR [Bundesforschungsanstalt für Landeskunde und Raumordnung] (1995), Materialien zur Raumentwicklung 67, Bonn.

Brüderl, J., P. Preisendörfer and R. Ziegler (1992), Survival chances of newly founded business organizations, American Sociological Review 57, 227-42.

Caves, R.E. (1998), Industrial organization and new findings on the turnover and mobility of firms, Journal of Economic Literature 36, 1947-82.

Evans, D.S. (1987), The relationship between firm growth, size, and age: estimates for 100 manufacturing industries, The Journal of Industrial Economics $35,567-81$.

Ericson, R. and A. Pakes (1995), "Markov-perfect industry dynamics: a framework for empirical work", Review of Economic Studies 62, 53-82.

Geroski, P.A. (1995), What do we know about entry?, International Journal of Industrial Organization 13, 421-40.

Harhoff, D., K. Stahl and M. Woywode (1998), Legal form, growth and exit of West German firms - empirical results for manufacturing construction, trade and service industries, The Journal of Industrial Economics 96, 45389.

Hujer, R., K.-O. Maurer and M. Wellner (1997), The Impact of Training on Unemployment Duration in West Germany, Discussion Paper 74, Department of Economics, Johann Wolfgang Goethe-University, Frankfurt.

Lechner, M., F. Pfeiffer, H. Spengler and M. Almus (2000), The Impact of Non-profit Temping Agencies on Individual Labour Market Success in the West German State of Rhineland-Palatinate, Discussion Paper 00-02, Centre for European Economic Research (ZEW), Mannheim. 
Maddala, G.S. (1983), Limited-Dependent and Qualitative Variables in Econometrics, Cambridge University Press, Cambridge.

Olley, G.O. and A. Pakes (1996), The dynamics of productivity in the telecommunications equipment industry, Econometrica 64, 1263-97.

Prantl, S. (2000), Post-Entry Selection among Newly Founded Firms in East and West Germany after Unification, mimeo, University of Mannheim.

Rajan, G.R. and L. Zingales (1998), Power in a theory of the firm, The Quarterly Journal of Economics 113, 387-432.

Rosenbaum, P.R. and D.B. Rubin (1983), The central role of the propensity score in observational studies for causal effects, Biometrika 70, 41-55.

Schmalensee, R. (1989), Inter-Industry Studies of Structure and Performance, in Schmalensee, R. and R. Willig (eds.), Handbook of Industrial Organization 2, Amsterdam, North-Holland.

Storey, D.J. (1994), Understanding the small business sector, Routledge, London.

Sutton, J. (1997), Gibrats's legacy, Journal of Economic Literature 35, 40-59.

Wagner, J. (1999), The life history of cohorts of exists from German manufacturing, Small Business Economics 13, 71-79.

Yatchew, A. (1998), Nonparametric Regression Techniques in Economics, Journal of Economic Literature 36, 669-721. 


\section{A Appendix}

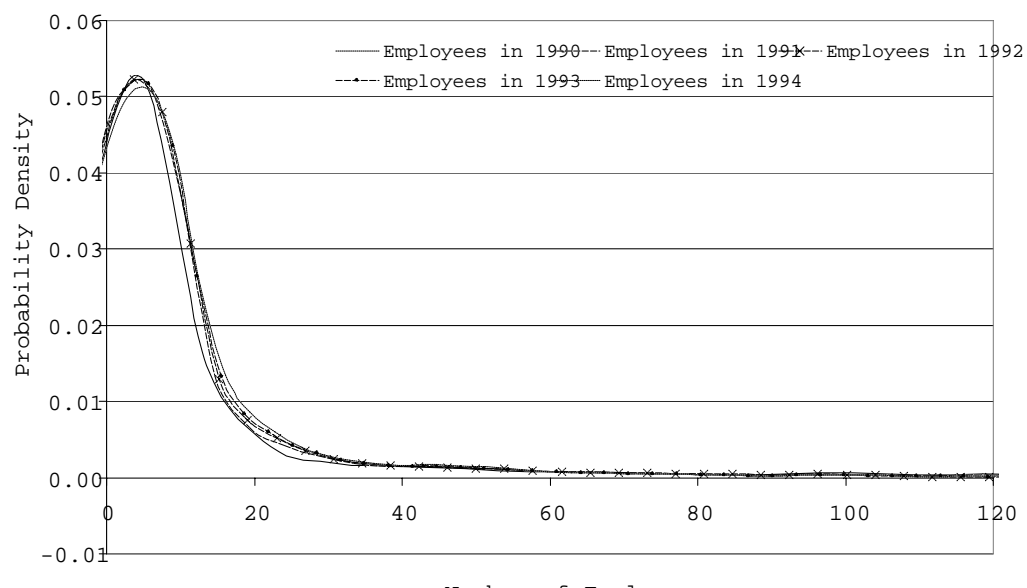

Number of Employees

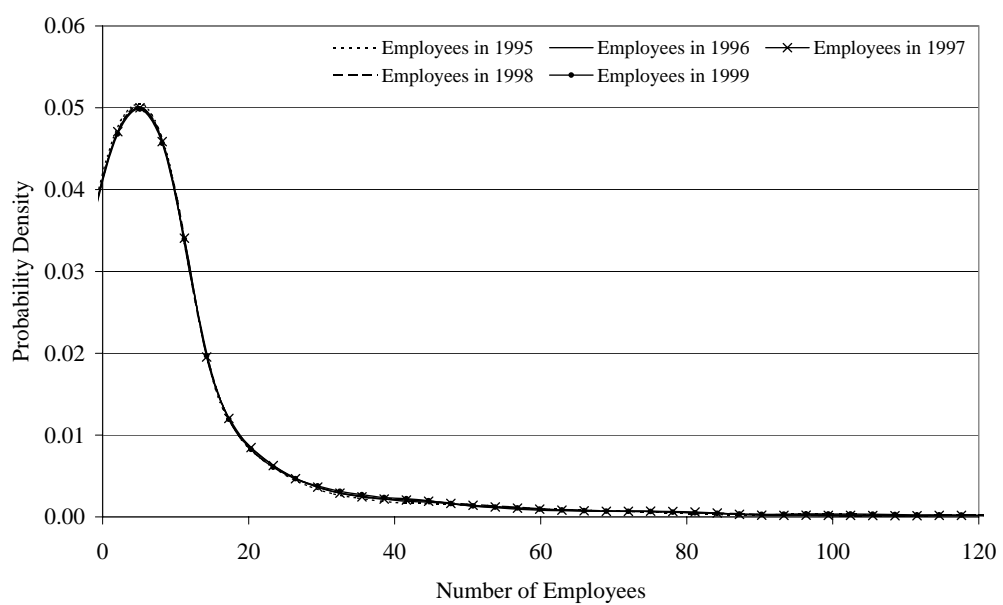

Source: ZEW-Foundation Panels East and West, telephone survey.

Figure 1: Kernel density estimates of firm size from 1990 until 1999 

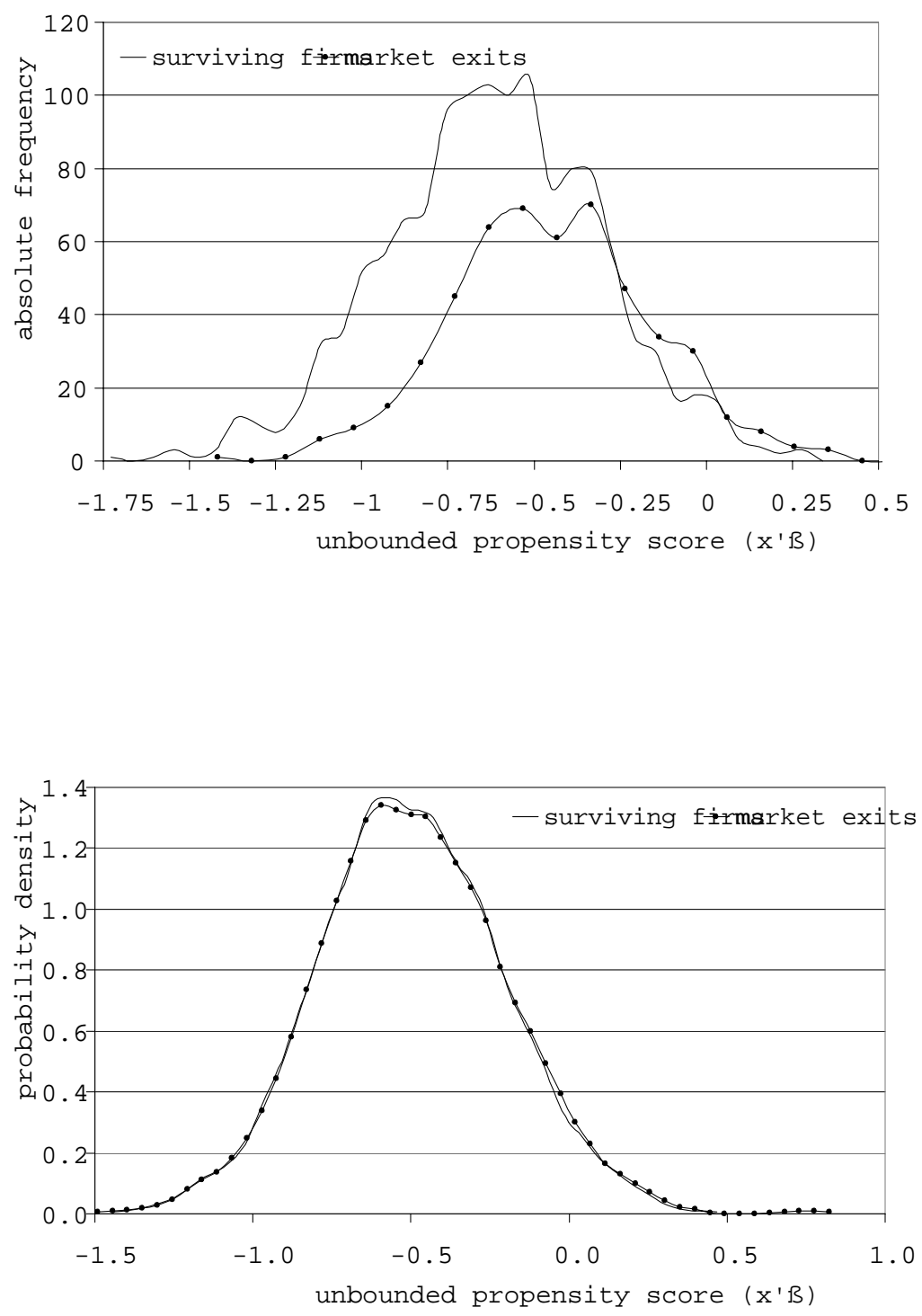

Source: ZEW-Foundation Panels East and West, telephone survey.

Figure 2: Histograms and kernel density estimates of the unbounded propensity scores $\left(x^{\prime} \beta\right)$ before and after the matching process 
Table 1: Descriptive Statistics

\begin{tabular}{|c|c|c|}
\hline variable & mean/share & STDV \\
\hline \multicolumn{3}{|l|}{ average growth rate in } \\
\hline $1990 / 91$ & 0.184 & 0.421 \\
\hline $1991 / 92$ & 0.149 & 0.340 \\
\hline $1992 / 93$ & 0.107 & 0.297 \\
\hline $1993 / 94$ & 0.109 & 0.342 \\
\hline $1994 / 95$ & 0.054 & 0.278 \\
\hline $1995 / 96$ & 0.024 & 0.253 \\
\hline $1996 / 97$ & 0.005 & 0.269 \\
\hline $1997 / 98$ & 0.005 & 0.263 \\
\hline $1998 / 99$ & -0.018 & 0.276 \\
\hline \multicolumn{3}{|l|}{ firms founded in } \\
\hline 1990 & 0.276 & / \\
\hline 1991 & 0.268 & / \\
\hline 1992 & 0.245 & / \\
\hline 1993 & 0.211 & 1 \\
\hline \multicolumn{3}{|l|}{ number of firm owners } \\
\hline one & 0.494 & / \\
\hline 2 till 4 & 0.470 & / \\
\hline 5 or more & 0.019 & / \\
\hline missing & 0.017 & / \\
\hline \multicolumn{3}{|l|}{ industry classification } \\
\hline manufacturing & 0.125 & / \\
\hline building & 0.196 & / \\
\hline trade & 0.458 & / \\
\hline services & 0.221 & 1 \\
\hline \multicolumn{3}{|c|}{ human capital endowment of founder(s) } \\
\hline very high & 0.035 & / \\
\hline high & 0.277 & / \\
\hline medium & 0.427 & / \\
\hline low & 0.039 & / \\
\hline missing & 0.221 & / \\
\hline \multicolumn{3}{|l|}{ regional origin } \\
\hline founded in Western Germany & 0.406 & / \\
\hline county with high density & 0.453 & / \\
\hline county with medium density & 0.349 & / \\
\hline county with low density & 0.197 & 1 \\
\hline firms involved in start-up & 0.086 & / \\
\hline size at start-up & 6.675 & 24.050 \\
\hline liability limiting legal form & 0.421 & 1 \\
\hline number of observation & \multicolumn{2}{|c|}{1,795} \\
\hline
\end{tabular}


Table 2: Mean comparison of selected variables between survivors and market exits

\begin{tabular}{|c|c|c|c|}
\hline \multirow[t]{2}{*}{ variable } & \multicolumn{2}{|c|}{ mean of variable } & \multirow[t]{2}{*}{ t-value } \\
\hline & surviving firms & market exits & \\
\hline initial size & 8.024 & 8.529 & -0.249 \\
\hline start-up in 1990 & 0.308 & 0.314 & -0.203 \\
\hline start-up in 1991 & 0.272 & 0.272 & 0.000 \\
\hline start-up in 1992 & 0.262 & 0.260 & 0.071 \\
\hline start-up in 1993 & 0.158 & 0.154 & 0.173 \\
\hline liability limiting legal form & 0.464 & 0.465 & -0.063 \\
\hline manufacturing (low tech) & 0.073 & 0.081 & -0.471 \\
\hline manufacturing (high tech) & 0.022 & 0.028 & -0.607 \\
\hline building (basic construction) & 0.061 & 0.090 & $-1.779^{*}$ \\
\hline building (installation \& completion) & 0.947 & 0.101 & -0.317 \\
\hline car trade & 0.071 & 0.063 & 0.502 \\
\hline retail trade & 0.101 & 0.120 & -1.001 \\
\hline wholesale & 0.284 & 0.223 & $2.241^{* *}$ \\
\hline transport \& communication & 0.057 & 0.069 & -0.774 \\
\hline business related services & 0.178 & 0.156 & 0.926 \\
\hline consumption related servíces & 0.059 & 0.069 & -0.641 \\
\hline firms involved in start-up & 0.059 & 0.053 & 0.409 \\
\hline one firm owner & 0.418 & 0.432 & -0.444 \\
\hline 2 till 4 owner persons & 0.540 & 0.521 & 0.629 \\
\hline 5 or more owner persons & 0.014 & 0.026 & -1.355 \\
\hline number of owner persons missing & 0.028 & 0.022 & 0.607 \\
\hline very high human capital & 0.047 & 0.039 & 0.616 \\
\hline high human capital & 0.308 & 0.296 & 0.410 \\
\hline nedium human capital & 0.375 & 0.393 & -0.581 \\
\hline low human capital & 0.053 & 0.061 & -0.541 \\
\hline missing human capital & 0.217 & 0.211 & 0.230 \\
\hline start-up in Western Germany & 0.477 & 0.473 & 0.123 \\
\hline high dense county & 0.491 & 0.458 & 0.107 \\
\hline medium dense county & 0.351 & 0.365 & -0.458 \\
\hline low dense county & 0.158 & 0.178 & -0.840 \\
\hline unbounded propensity score $\left(x_{i}^{\prime} \hat{\beta}\right)$ & -0.450 & -0.494 & -0.840 \\
\hline number of observations & 507 & 507 & / \\
\hline
\end{tabular}

Source: ZEW-Foundation Panels East and West, telephone survey.

Note: ${ }^{* *}\left({ }^{*}\right)$ indicate significant different means between

both groups in a mutual t-test at the 5 (10) per cent level. 
Table 3: Comparison of the continuous employment growth rates based on the matched pairs for several exit cohorts

\begin{tabular}{lcccc}
\hline & \multicolumn{5}{c}{ year of market exit } \\
& 1998 & 1997 & 1996 & 1995 \\
\hline period $(t, t-1)$ & & & & \\
growth rate exits & -0.080 & -0.101 & -0.062 & -0.114 \\
growth rate survivors & $-0.127^{*}$ & $0.023^{* *}$ & $0.078^{* *}$ & $0.080^{* *}$ \\
observations in each group & 63 & 73 & 68 & 79 \\
period $(t-1, t-2)$ & & & & \\
growth rate exits & -0.064 & -0.013 & 0.016 & 0.023 \\
growth rate survivors & $0.052^{* *}$ & $0.078^{* *}$ & 0.046 & $0.148^{* *}$ \\
observations in each group & 63 & 73 & 68 & 79 \\
period $(t-2, t-3)$ & & & & \\
growth rate exits & -0.021 & 0.027 & 0.094 & 0.050 \\
growth rate survivors & 0.006 & 0.059 & $0.213^{*}$ & 0.056 \\
observations in each group & 63 & 73 & 68 & 64 \\
period $(t-3, t-4)$ & & & & \\
growth rate exits & -0.003 & 0.081 & 0.015 & 0.114 \\
growth rate survivors & 0.061 & 0.128 & $0.130^{*}$ & 0.111 \\
observations in each group & 63 & 73 & 55 & 50 \\
$\begin{array}{l}\text { period }(t-4, t-5) \\
\text { growth rate exits }\end{array}$ & 0.118 & 0.085 & 0.164 & 0.049 \\
growth rate survivors & 0.099 & 0.114 & 0.152 & $0.204^{*}$ \\
observations in each group & 63 & 56 & 36 & 23 \\
\hline
\end{tabular}

Source: ZEW-Foundation Panels East and West, telephone survey.

Note: $\quad{ }^{* *}\left({ }^{*}\right)$ indicate a significantl higher growth rate of the surviving firms in a mutual t-test at the 5 (10) per cent level. 
Table 4: Comparison of the continuous employment growth rates based on the matched pairs differentiated between Eastern and Western Germany

\begin{tabular}{|c|c|c|c|}
\hline & \multicolumn{3}{|c|}{ Pooling $^{a}$ ) of the observations for } \\
\hline & Eastern Germany & Western Germany & Germany \\
\hline \multicolumn{4}{|l|}{ period $(t, t-1)$} \\
\hline growth rate exits & -0.130 & -0.042 & -0.090 \\
\hline growth rate survivors & $0.032^{* *}$ & $0.030^{* *}$ & $0.032^{* *}$ \\
\hline observations in each group & 155 & 128 & 283 \\
\hline \multicolumn{4}{|l|}{ period $(t-1, t-2)$} \\
\hline growth rate exits & -0.015 & 0.003 & -0.007 \\
\hline growth rate survivors & $0.067^{* *}$ & $0.106^{* *}$ & $0.084^{* *}$ \\
\hline observations in each group & 155 & 128 & 283 \\
\hline \multicolumn{4}{|l|}{ period $(t-2, t-3)$} \\
\hline growth rate exits & 0.051 & 0.023 & 0.038 \\
\hline growth rate survivors & 0.087 & $0.080^{*}$ & $0.084^{*}$ \\
\hline observations in each group & 148 & 120 & 268 \\
\hline \multicolumn{4}{|l|}{ period $(t-3, t-4)$} \\
\hline growth rate exits & 0.074 & 0.020 & 0.051 \\
\hline growth rate survivors & 0.099 & $0.119^{* *}$ & $0.107^{* *}$ \\
\hline observations in each group & 137 & 104 & 241 \\
\hline \multicolumn{4}{|l|}{ period $(t-4, t-5)$} \\
\hline growth rate exits & 0.138 & 0.070 & 0.108 \\
\hline growth rate survivors & 0.159 & 0.090 & 0.128 \\
\hline observations in each group & 100 & 78 & 178 \\
\hline
\end{tabular}

Source: ZEW-Foundation Panels East and West, telephone survey.

Note: ${ }^{* *}\left({ }^{*}\right)$ indicate a significantly higher growth rate of the surviving firms in a mutual t-test at the 5 (10) per cent level.

a) Pooling for the period $(t-2, t-3)$, for example, includes the growth rates in 1995/96 for exits in 1998 as well as the matched pairs up to the growth rates in 1992/93 for market exits in 1995 and their matched pairs 
Table 5: Share of firms that gradually decreases employment

\begin{tabular}{lcccc}
\hline & \multicolumn{5}{c}{ year of market exit } \\
& 1998 & 1997 & 1996 & 1995 \\
\hline exiting firms & & & \\
decreasing or stagnating employment before market exit \\
at least 5 years (in per cent) & 0.714 & 0.425 & 0.324 & 0.228 \\
at least 4 years (in per cent) & 0.825 & 0.658 & 0.559 & 0.380 \\
at least 3 years (in per cent) & 0.873 & 0.726 & 0.750 & 0.570 \\
at least 2 years (in per cent) & 0.873 & 0.836 & 0.824 & 0.810 \\
at least 1 year (in per cent) & 0.968 & 0.904 & 0.926 & 0.937 \\
\hline matched surviving firms & & & & \\
decreasing or stagnating employment & & \\
at least 5 years (in per cent) & 0.492 & 0.260 & 0.176 & 0.114 \\
at least 4 years (in per cent) & 0.556 & 0.425 & 0.265 & 0.316 \\
at least 3 years (in per cent) & 0.635 & 0.479 & 0.412 & 0.392 \\
at least 2 years (in percent) & 0.714 & 0.616 & 0.603 & 0.595 \\
at least 1 years (in per cent) & 0.857 & 0.767 & 0.735 & 0.722 \\
\hline
\end{tabular}

Source: ZEW-Foundation Panels East and West, telephone survey.

Table 6: Growth of GDP in Germany (in per cent)

\begin{tabular}{lccc}
\hline year & Germany & Eastern Germany & Western Germany \\
\hline 1990 & 5.1 & $/$ & $/$ \\
1991 & 3.7 & $/$ & 9.1 \\
1992 & 7.9 & 28.9 & 6.2 \\
1993 & 2.8 & 21.7 & 1.0 \\
1994 & 5.2 & 13.3 & 4.3 \\
1995 & 3.4 & 7.3 & 3.0 \\
1996 & 2.3 & 4.6 & 2.0 \\
1997 & 2.9 & 2.5 & 2.9 \\
1998 & 3.7 & 1.8 & 3.9 \\
\hline Source: & Federal Statistical Office, Federal Department of \\
\multicolumn{4}{c}{ Trade and Industry. } \\
Note:
\end{tabular}

